\title{
PEMBELAJARAN BIOLOGI DENGAN PENDEKATAN CTL DENGAN TEKNIK NETWORK TREE DAN SPIDER CONCEPT MAP DITINJAU DARI KREATIVITAS DAN GAYA BERPIKIR PESERTA DIDIK
}

\author{
${ }^{1}$ Mukayatun, ${ }^{2}$ Sugiyarto, dan ${ }^{3}$ Puguh Karyanto \\ ${ }^{1}$ Program Studi Pendidikan Sains, Program Pascasarjana, Universitas Sebelas Maret Surakarta \\ Bojonegoro, 62181, Indonesia \\ muka.yatun@yahoo.co.id \\ ${ }^{2}$ Program Studi Pendidikan Sains, Program Pascasarjana, Universitas Sebelas Maret Surakarta \\ Surakarta, 57126, Indonesia \\ sugiyarto_ys@yahoo.com \\ ${ }^{3}$ Program Studi Pendidikan Sains, Program Pascasarjana, Universitas Sebelas Maret Surakarta \\ Surakarta, 57126, Indonesia \\ karyarina@yahoo.com
}

\begin{abstract}
ABSTRAK
Tujuan penelitian untuk mengetahui pengaruh pembelajaran Biologi dengan pendekatan CTL dengan teknik network tree dan spider concept map ditinjau dari kreativitas dan gaya berpikir terhadap hasil belajar peserta didik. Penelitian ini dilaksanakan pada bulan September-Nopember 2012, menggunakan metode eksperimen. Populasi seluruh peserta didik kelas VII SMP Negeri 1 Sukosewu Bojonegoro tahun pelajaran 2012/2013. Sampel diperoleh dengan teknik cluster random sampling terdiri dari 4 kelas yaitu VII B, VII D, VII E, dan VII F. Teknik pengumpulan data menggunakan metode tes untuk hasil belajar kognitif, kreativitas, dan gaya berpikir. Metode angket untuk hasil belajar afektif. Metode observasi untuk mendapatkan hasil belajar afektif dan psikomotor. Data dianalisis menggunakan anava tiga jalan dengan desain faktorial 2 × 2 × 2 . Berdasarkan analisis disimpulkan: 1. ada pengaruh penggunaan pendekatan CTL dengan teknik network tree dan spider concept map terhadap hasil belajar afektif dan psikomotor, sedangkan kognitif tidak berpengaruh; 2 . ada pengaruh kreativitas tinggi dan rendah terhadap hasil belajar kognitif dan afektif, sedangkan psikomotor tidak berpengaruh; 3 . tidak ada pengaruh gaya berpikir sekuensial dan acak terhadap hasil belajar kognitif, afektif, dan psikomotor; 4. tidak ada interaksi antara pendekatan CTL dengan teknik network tree dan spider concept map dengan kreativitas terhadap hasil belajar kognitif, afektif, dan psikomotor; 5. ada interaksi antara pendekatan CTL dengan teknik network tree dan spider concept map dengan gaya berpikir terhadap hasil belajar psikomotor sedangkan kognitif dan afektif tidak ada interaksi; 6. ada interaksi antara kreativitas dan gaya berpikir terhadap hasil belajar kognitif sedangkan afektif dan psikomotor tidak ada interaksi; 7. tidak ada interaksi antara pendekatan CTL dengan teknik network tree dan spider concept map, kreativitas, dan gaya berpikir terhadap hasil belajar kognitif, afektif, dan psikomotor.
\end{abstract}

Kata Kunci: Pendekatan Contextual Teaching and Learning (CTL), network tree, spider concept map, kreativitas, gaya berpikir.

\section{Pendahuluan}

Keberhasilan belajar merupakan tanggung jawab bersama pihak sekolah, orang tua maupun masyarakat/lingkungan. Banyak faktor yang dapat mempengaruhi prestasi belajar peserta didik. Faktor-faktor yang mempengaruhi hasil belajar mengajar dapat dikelompokkan menjadi faktor internal dan eksternal. 1) Faktor internal merupakan faktor yang berasal dari diri peserta didik meliputi jasmaniah, psikologis, dan kelelahan; 2) eksternal merupakan faktor yang berasal dari luar peserta didik meliputi keluarga, sekolah, dan masyarakat (Slameto, 2010).

Berkaitan dengan proses pembelajaran, peraturan pemerintah (PP) nomor 19 tahun 
2005 tentang standar proses menyiratkan bahwa pembelajaran yang diselenggarakan hendaknya terlaksana secara interaktif, inspiratif, menyenangkan, menantang, memotifasi peserta didik untuk berpartisipasi aktif, serta memberikan ruang yang cukup bagi prakarsa, kreativitas, dan kemandirian sesuai bakat, minat dan perkembangan fisik serta psikologis peserta didik. Kemampuan peserta didik untuk interaktif, inspiratif, partisipasi aktif, prakarsa, kreativitas, dan mandiri tersebut merupakan hal yang sangat dibutuhkan dalam mempelajari IPA.

Pembelajaran IPA atau sains mempunyai karakteristik pada produk, proses, dan aplikasi. Pembelajaran IPA atau sains menuntut bahwa dalam proses pembelajaran guru harus melibatkan peserta didik secara aktif dan kreatif sesuai dengan tahap perkembangan peserta didik. Supaya hal tersebut dapat terwujud dikembangkan Kurikulum Tingkat Satuan Pendidikan (KTSP). KTSP bertujuan memandirikan dan memberdayakan satuan pendidikan melalui pemberian kewenangan (otonomi) kepada lembaga pendidikan dengan prinsip diantaranya berpusat pada potensi, pengembangan, kebutuhan, dan kepentingan peserta didik dan lingkungan, serta tanggap terhadap perkembangan ilmu pengetahuan, teknologi, dan seni.

Pelajaran IPA mempunyai ciri-ciri yang bukan sekedar mengedepankan fakta-fakta, konsep-konsep atau prinsip-prinsip tetapi juga proses penemuan. Pembelajaran IPA juga menekankan pada pentingnya produk dan proses. IPA merupakan pelajaran dengan karakteristik khusus yaitu ilmu pengetahuan diperoleh melalui pengumpulan data dan eksperimen, pengamatan dan deduksi untuk menghasilkan suatu penjelasan tentang sebuah gejala yang dapat dipercaya (BSNP, 2006). Menurut Carin et al. (1990 dalam Rustaman, 2005) sains mengandung 4 hal, yaitu konten atau produk, proses atau metode, sikap, dan teknologi. Produk meliputi fakta, hukum, prinsip, dan teori. Proses atau metode untuk mendapatkan pengetahuan. Sikap meliputi tekun, terbuka, jujur, dan obyektif. Teknologi bahwa sains mempunyai keterkaitan digunakan dalam kehidupan sehari-hari.

Dalam pembelajaran IPA guru sebagai pengelola proses pembelajaran sangat mempengaruhi peningkatan hasil belajar. Guru hendaknya dapat memilih dan melaksanakan proses pembelajaran sesuai dengan karakteristik materi pelajaran dan karekteristik peserta didik. Dengan memperhatikan karakteristik materi pelajaran, guru dapat menentukan model yang sesuai dengan materi pelajaran sehingga pelajaran dapat dipahami oleh peserta didik dengan mudah. Perhatian pada peserta didik juga diperlukan karena kemampuan dan bakat peserta didik berbeda, menjadikan perbedaan pada model yang diterapkan.

Pelajaran IPA-Biologi yang mempelajari makhluk hidup dan gejala-gejala yang ada di sekitarnya tidak dapat lepas dari ketiga ranah dalam hasil belajar. Kemampuan yang diharapkan dari proses belajar merupakan kecakapan-kecakapan potensial atau kapasitas yang dimiliki seseorang. Kemampuan dapat dikelompokan menjadi tiga kelompok (ranah) yaitu kemampuan berpikir (kognitif), sikap (afektif) dan kemampuan gerak/perbuatan tubuh (psikomotorik). Kemampuan kognitif merupakan kemampuan menggunakan pengetahuan dalam berbagai situasi, sesuai dengan konteksnya. Kemampuan afektif berkaitan dengan sikap, perilaku, konsep diri, dan minat belajar peserta didik, sedangkan kemampuan psikomotorik yaitu kemampuan berkaitan dengan gerak tubuh. Ketiga ranah tersebut tidak dapat dipisahkan dan menjadi landasan dalam menentukan rancangan proses pembelajaran serta sistem penilaianya yang tertuang dalam tujuan kurikulum sekolah.

Pembelajaran IPA-Biologi di SMP Negeri 1 Sukosewu umumnya pada proses pembelajaran peserta didik masih bersifat pasif dan aktif ketika diberikan tugas atau diperintah oleh guru. Metode pembelajaran yang digunakan umunya ceramah dan diskusi serta pemberian tugas. Jumlah peserta didik yang tidak tuntas dalam ulangan harian IPA-Biologi kelas VII semester gasal tahun pelajaran 2011/2012 tercantum dalam tabel 1 .

Penjelasan Tabel 1

Peserta didik paling banyak tidak tuntas pada materi pelajaran Klasifikasi Makhluk Hidup. Oleh sebab itu untuk menciptakan proses pembelajaran yang aktif diperlukan adanya pendekatan dan teknik pembelajaran yang sesuai. 
Tabel 1. Jumlah Peserta Didik yang Tidak Tuntas UH IPA- Biologi

\begin{tabular}{|c|c|c|c|c|c|c|c|}
\hline \multirow{2}{*}{ No. } & \multirow[b]{2}{*}{$\begin{array}{l}\text { Materi } \\
\text { Pelajaran } \\
\end{array}$} & \multicolumn{5}{|c|}{ Kelas VII } & \multirow[b]{2}{*}{$\mathrm{Jml}$} \\
\hline & & A & B & $\mathrm{C}$ & $\mathrm{D}$ & $\mathrm{E}$ & \\
\hline 1 & Gejala Alam & - & 3 & 4 & 2 & 3 & 12 \\
\hline 2 & Mikroskop & - & 3 & 5 & 3 & 4 & 15 \\
\hline 3 & $\begin{array}{l}\text { Keselamatan } \\
\text { Kerja }\end{array}$ & - & 1 & 2 & 2 & 2 & 7 \\
\hline 4 & $\begin{array}{l}\text { CiriMakhluk } \\
\text { Hidup }\end{array}$ & - & 2 & 3 & 4 & 4 & 13 \\
\hline \multirow[t]{2}{*}{5} & $\begin{array}{l}\text { Klasifikasi } \\
\text { Makhluk Hidup }\end{array}$ & 2 & 4 & 5 & 6 & 4 & 21 \\
\hline & Jumlah & 22 & 20 & 20 & 20 & 20 & \\
\hline
\end{tabular}

Keterampilan guru dalam pengembangan pendekatan dan teknik masih kurang dan terpusat pada guru (teacher centered). Hal tersebut menyebabkan peserta didik bersifat pasif. Jika tidak dilakukan perubahan proses pembelajaran, maka peserta didik yang menerima pembelajaran secara teacher centered, tingkat berpikirnya hanya pada tahap mengingat dan menghafal, jika diberikan soal penerapan (C3) dan menganalisis (C4) secara umum belum mampu menyelesaiakan dengan baik. Sehingga perlu dilakukan upaya perbaikan supaya ada peningkatan hasil belajar.

Pemilihan pendekatan pembelajaran yang tepat akan membantu berhasilnya proses pembelajaran di kelas. Pendekatan pembelajaran yang dapat dijadikan sebagai alternatif untuk memberikan variasi pada proses pembelajarn adalah pendekatan Contextual Teaching and Learning (CTL). Pembelajaran kontekstual adalah suatu pendekatan pembelajaran yang menekankan pada proses keterlibatan peserta didik secara langsung dapat menemukan materi yang dipelajari dan menghubungkan dengan situasi kehidupan dunia nyata sehingga mendorong peserta didik untuk dapat menerapkannya dalam kehidupan sehari-hari (Berns, 2001; Wasis, 2006).

Pembelajaran dengan pendekatan Contextual Teaching and Learning akan meningkatkan prestasi belajar karena sesuai dengan nurani manusia yang selalu bermakna (Nurdin, 2009), mampu memuaskan kebutuhan otak untuk menguatkan otak dalam mengaitkan informasi baru dengan pengetahuan yang sudah ada, yang merangsang pembentukan struktur fisik otak dalam rangka merespon lingkungan. Dalam pembelajaran kontekstual akan membantu guru mengaitkan konten materi pelajaran dengan situasi dunia nyata dan memotivasi peserta didik membuat hubungan antara pengetahuan dan penerapannya dalam kehidupan mereka (Johnson, 2011).

Melalui pendekatan kontekstual diharapkan peserta didik belajar dari pengalaman sendiri bukan dari orang lain, pengetahuan dan keterampilan itu diperluas dari konteks-konteks yang terbatas (sempit) dan sedikit-sedikit dan penting bagi peserta didik tahu manfaat belajar dan cara dia menggunakan pengetahuan dan ketrampilan. Materi yang diterima dari pengamatan yang telah dilakukan akan mengembangkan asimilasi dan membentuk akomodasi pada diri peserta didik. Asimilasi merupakan proses kognitif yang mengintegrasikan persepsi, konsep atau pengalaman baru ke dalam skema yang sudah ada di pikirannya. Akomodasi adalah membentuk atau memodifikasi skema dari proses asimilasi. Peserta didik yang mengikuti pembelajaran kontekstual akan mengalami asimilasi dan akomodasi sehingga mendapatkan pengalaman yang tidak mudah dilupakan dan dapat diterapkan dalam kehidupan sehari-hari (Suparno, 2012).

Menurut Trianto (2008) pendekatan kontekstual pada dasarnya menekankan pentingnya peserta didik membangun sendiri pengetahuan melalui keterlibatan dalam proses belajar-mengajar. Membangun pengetahuan sesuai dengan pandangan konstruktivisme, bahwa belajar berarti membentuk makna. Makna diciptakan oleh peserta didik dari yang mereka lihat, dengar, rasakan, dan alami. Menurut teori konstruktivisme mengajar bukanlah kegiatan memindahkan pengetahuan dari guru ke peserta didik, melainkan suatu kegiatan yang memungkinkan peserta didik membangun sendiri pengetahuannya.

Keberhasilan proses belajar mengajar secara tidak langsung juga dipengaruhi oleh teknik yang digunakan dalam mengajar guru Hay (et al. 2008). Teknik dalam pembelajaran diantaranya adalah menggunakan peta konsep jenis network tree dan spider concept map. network ree (diagram pohon) merupakan bagian peta konsep dalam bentuk diagram yang memuat ide-ide pokok yang dibuat dalam 
persegi empat, sedangkan beberapa kata yang lain dituliskan pada garis-garis penghubung yang menunjukkan dari perihal umum ke khusus (Trianto, 2011). Teknik network tree merupakan suatu yang hierarki, disusun dengan sistematis menunjukkan hubungan antara ideide sehingga mampu menghubungkan konsep satu dengan yang lain, disajikan seperti ranting pohon. Spider concept map (peta konsep labalaba) merupakan bagian dari peta konsep dalam bentuk diagram yang memuat ide-ide berangkat dari suatu ide sentral, sehingga dapat memperoleh sejumlah besar ide yang belum tentu jelas hubungannya satu sama lain (Trianto, 2011). Teknik spider concept map merupakan suatu yang tidak menurut hierarki sehingga ada kebebasan menaruh sub konsep pada sisi kanan atau kiri, disajikan seperti labalaba (Fuata'i, 2004; Polancos, 2011).

Keberhasilan proses belajar mengajar juga dapat dipengaruhi oleh kreativitas peserta didik (Lasiran, 2011). Keativitas adalah suatu proses yang menghasilkan sesuatu yang baru hasil interaksi antara individu dengan lingkungannya. Munandar (2009) bahwa salah satu faktor untuk menentukan keberbakatan seseorang adalah kreativitas untuk berprestasi. Kreativitas atau daya cipta memungkinkan penemuan-penemuan baru dalam bidang ilmu dan teknologi serta dalam semua bidang usaha maupun lainnya.

Faktor lain yang dapat mempengaruhi keberhasilan proses belajar mengajar adalah gaya berpikir. Gaya berpikir adalah suatu bentuk perilaku yang diakibatkan oleh dominansi otak (kiri atau kanan) dalam memproses informasi hingga menciptakan solusi yang lebih seimbang untuk menyelesaikan permasalahan dalam situasi dan kondisi rangsangan yang berbeda-beda. (DePorter dan Hernachi, 2011)

Gaya berpikir dibedakan menjadi dua yaitu sekuensial dan acak. Gaya berpikir sekuensial dibedakan menjadi: sekuensial konkret dan sekuensial abstrak sedangkan gaya berpikir acak dibedakan menjadi acak konkret dan acak abstrak. Seseorang yang memiliki gaya berpikir sekuensial cenderung memiliki dominasi otak kiri, sedangkan seseorang seseorang yang memiliki gaya berpikir acak cenderung memiliki dominansi otak kanan dalam memproses informasi untuk menghasilkan solusi terhadap permasalahan atau informasi yang diterima melalui alat indera (Ristasa, 2012). Aktivitas yang berbeda akan memerlukan cara berpikir yang berbeda pula. Keuntungan seseorang mengetahui gaya berpikirnya adalah dirinya dapat mengetahui cara yang lebih dominan.

Berdasarkan latar belakang di atas dan dalam rangka meningkatkan hasil belajar serta solusi terhadap permasalahan peserta didik di SMP Negeri 1 Sukosewu Bojonegoro perlu dilakukan penelitian dengan judul pembelajaran biologi dengan pendekatan CTL dengan teknik network tree dan spider concept map ditinjau dari kreativitas dan gaya berpikir peserta didik.

Tujuan dari penelitian ini adalah untuk mengetahui pengaruh pendekatan CTL dengan teknik network tree dan spider concept map ditinjau dari kreativitas dan gaya berpikir terhadap hasil belajar peserta didik.

\section{Metode Penelitian}

Penelitian dilaksanakan di SMPN 1 Sukosewu Bojonegoro. Waktu penelitian dimulai bulan September sampai dengan bulan Nopember tahun 2012. Penelitian ini termasuk penelitian eksperimen. Kelompok I menggunakan teknik network tree dan kelompok II menggunakan teknik spider concept map.

Rancangan penelitian yang digunakan adalah rancangan anava 3 jalan dengan rancangan faktorial 2 x 2 x 2 . Teknik pengambilan sampel yang digunakan dalam penelitian ini adalah teknik cluster random sampling. Sampel yang digunakan dalam penelitian ini ada 4 kelas yaitu kelas VII B dan VII D sebagai kelas eksperimen I dan kelas VII E dan VII F sebagai kelas eksperimen II.

Teknik pengumpulan data dalam penelitian ini menggunakan: (1) metode tes, digunakan untuk kreativitas, gaya berpikir, dan hasil belajar ranah kognitif dan psikomotor, (2) metode angket, digunakan untuk memperoleh data ranah afektif; 3) Metode observasi, digunakan untuk mengambil data selama proses pembelajaran ranah afektif dan psikomotor.

Instrumen pelaksanaan penelitian berupa silabus, rencana pelaksanaan pembelajaran (RPP) teknik network tree dan spider concept map, instrumen pengambilan data digunakan tes, angket, dan lembar observasi. Pengujian 
hipotesis dilakukan dengan uji anava menggunakan bantuan PASW 18.

\section{Hasil Penelitian}

Hasil penelitian berupa data hasil belajar kognitif, afektif, dan psikomotor, data kreativitas dan gaya berpikir. Kelas VII B dan VII D jumlah 54 sebagai kelas eksperimen I pendekatan CTL dengan teknik network tree dan kelas VII E dan VII F jumlah 52 sebagai kelas eksperimen II pendekatan CTL dengan teknik spider concept map. Data nilai berdasarkan gaya berpikir diambil dari peserta didik yang memiliki gaya berpikir sekuensial dan acak, sehingga jumlah sampel kelas network tree sebanyak 43 dan kelas spider concept map 47. Data kreativitas diperoeh melalui tes selanjutnya dikelompokkan menjadi dua kategori yaitu kreativitas tinggi $\geq$ nilai rerata jumlah 56 dan kreativitas rendah < rerata nilai tes jumlah 34 .

Tabel 2. Rata-Rata Hasil Belajar Berdasarkan Teknik Pembelajaran, Kreativitas, dan Gaya Berpikir

\begin{tabular}{|c|c|c|c|c|}
\hline \multirow[b]{2}{*}{ Variabel } & \multirow[b]{2}{*}{ Aspek } & \multicolumn{3}{|c|}{ Hasil Belajar } \\
\hline & & $\begin{array}{c}\text { Kogni } \\
\text { tif }\end{array}$ & Afektif & $\begin{array}{l}\text { Psiko } \\
\text { motor }\end{array}$ \\
\hline Teknik & Network tree & 58,20 & 65,40 & 70,05 \\
\hline $\begin{array}{l}\text { Pembe } \\
\text { lajaran }\end{array}$ & $\begin{array}{l}\text { Spider } \\
\text { concept map }\end{array}$ & 54,30 & 60,57 & 64,72 \\
\hline Kreati & Tinggi & 60,70 & 62,75 & 67,84 \\
\hline vitas & Rendah & 48,71 & 60,76 & 66,32 \\
\hline Gaya & Sekuensial & 55,13 & 62,85 & 67,16 \\
\hline Berpikir & Acak & 57,80 & 62,91 & 67,43 \\
\hline
\end{tabular}

Rata-rata hasil belajar berdasarkan: 1 . teknik pembelajaran, peserta didik yang belajar menggunakan teknik network tree memperoleh hasil belajar kognitif, afektif, dan psikomotor lebih baik dari pada yang menggunakan spider concept map; 2 . kreativitas, peserta didik yang memiliki kreativitas tinggi memperoleh hasil belajar kognitif, afektif, dan psikomotor lebih baik dari pada yang memiliki kreativitas rendah; 3. gaya berpikir, peserta didik yang memiliki gaya berpikir acak memperoleh hasil belajar kognitif, afektif, dan psikomotor lebih baik dari pada yang memiliki gaya berpikir sekuensial (Tabel 2).

Hasil uji Anava dengan langkah General Linear Model (GLM) baik prestasi kognitif, afektif, dan psikomotorik.

Tabel 3. Rangkuman Uji Anava

\begin{tabular}{clccc}
\hline $\begin{array}{c}\text { Hipo } \\
\text { tesis }\end{array}$ & \multicolumn{1}{c}{ Yang Diuji } & Kognitif & $\begin{array}{c}\text { P-value } \\
\text { Afektif }\end{array}$ & Psikomotor \\
\hline 1 & CTL & 0,701 & 0,000 & 0,027 \\
2 & Kreativias & 0,000 & 0,005 & 0,629 \\
3 & Gaya_berpikir & 0,745 & 0,972 & 0,757 \\
4 & CTL*Kreativitas & 0,581 & 0,357 & 0,747 \\
5 & CTL*Gaya_berpikir & 0,337 & 0,948 & 0,006 \\
6 & Kreativita** & 0,017 & 0,348 & 0,273 \\
& Gaya_Berpikir & & & 0,542 \\
7 & CTL*Kreativitas* & 0,989 & 0,366 & 0,542 \\
\hline
\end{tabular}

$P$-value $<0,05$ ranah kognitif pada kemampuan kreativitas dan interaksi antara kreativitas dengan gaya berpikir; ranah afektif pada pendekatan CTL dan kemampuan kreativitas; ranah psikomotor pada pembelajaran CTL dan interaksi antara CTL dengan gaya berpikir, sedangkan yang lain diperoleh $p$-value $>0,05$ (Tabel 3).

Tabel 4. Hasil Uji Lanjut Anava Hipotesis 5 Hasil belajar kognitif

\begin{tabular}{|c|c|c|c|}
\hline Interaksi (A) & Interaksi (B) & $\begin{array}{l}\text { Selisih Rerata } \\
\text { (A-B) }\end{array}$ & p-value \\
\hline $\begin{array}{l}\text { Network Tree- } \\
\text { Acak }\end{array}$ & $\begin{array}{l}\text { Spider CM- } \\
\text { Sekuensial }\end{array}$ & 4,2799 & .404 \\
\hline $\begin{array}{l}\text { Network Tree- } \\
\text { Sekuensial }\end{array}$ & $\begin{array}{l}\text { Network Tree } \\
\text {-Acak }\end{array}$ & 4,7466 & .329 \\
\hline $\begin{array}{l}\text { Network Tree- } \\
\text { Sekuensial }\end{array}$ & $\begin{array}{l}\text { Spider } C M \text { - } \\
\text { Acak }\end{array}$ & 4,2564 & .412 \\
\hline $\begin{array}{l}\text { Network Tree- } \\
\text { Sekuensial }\end{array}$ & $\begin{array}{l}\text { Spider CM- } \\
\text { Sekuensial }\end{array}$ & $9,0265^{*}$ & .002 \\
\hline $\begin{array}{l}\text { Spider Concept } \\
\text { Map-Acak }\end{array}$ & $\begin{array}{l}\text { Network Tree } \\
\text {-Acak }\end{array}$ & 0.4902 & .999 \\
\hline $\begin{array}{l}\text { Spider Concept } \\
\text { Map-Acak }\end{array}$ & $\begin{array}{l}\text { Spider } C M \text { - } \\
\text { Sekuensial }\end{array}$ & 4,7701 & .291 \\
\hline
\end{tabular}

Tabel 5. Hasil Uji Lanjut Anava Hipotesis 6 Hasil Belajar Kognitif

\begin{tabular}{|c|c|c|c|}
\hline Interaksi (A) & Interaksi (B) & $\begin{array}{l}\text { Selisih Rerata } \\
\text { (A-B) }\end{array}$ & $P$-value \\
\hline $\begin{array}{l}\text { Kreatif Rendah- } \\
\text { Sekuensial }\end{array}$ & $\begin{array}{l}\text { Kreativitas } \\
\text { Rendah-Acak }\end{array}$ & 6,5429 & .676 \\
\hline $\begin{array}{l}\text { Kreativitas } \\
\text { Tinggi-Acak }\end{array}$ & $\begin{array}{l}\text { Kretivitas } \\
\text { Rendah-Acak }\end{array}$ & $21,5714^{*}$ & .001 \\
\hline $\begin{array}{l}\text { Kreativitas } \\
\text { Tinggi-Acak }\end{array}$ & $\begin{array}{l}\text { Kre Rendah- } \\
\text { Sekuensial }\end{array}$ & $15,0286^{*}$ & .023 \\
\hline $\begin{array}{l}\text { Kreativitas } \\
\text { Tinggi-Acak }\end{array}$ & $\begin{array}{l}\text { Kre Tinggi- } \\
\text { Sekuensial }\end{array}$ & 9,1714 & .195 \\
\hline $\begin{array}{l}\text { Kreatif Tinggi- } \\
\text { Sekuensial }\end{array}$ & $\begin{array}{l}\text { Kreativias } \\
\text { Rendah-Acak }\end{array}$ & 12,4000 & .091 \\
\hline $\begin{array}{l}\text { Kreatif Tinggi- } \\
\text { Sekuensial }\end{array}$ & $\begin{array}{l}\text { Kre Rendah- } \\
\text { Sekuensial }\end{array}$ & 5,8571 & .596 \\
\hline
\end{tabular}




\section{Pembahasan}

Data yang terkumpul dalam penelitian ini terdiri atas data kreativitas, gaya berpikir, hasil belajar kognitif, afektif, dan psikomotor. Data tersebut diperoleh dari kelas VII B dan VII D sebagai kelas dengan perlakuan eksperimen I pendekatan CTL dengan teknik network tree dan kelas VII E dan VII F sebagai kelas dengan perlakuan eksperimen II pendekatan CTL dengan teknik spider concept map.

Materi Kompetensi Dasar (KD) 6.2 "Mengklasifikasikan makhluk hidup berdasarkan ciri-ciri yang dimiliki" pada silabus dari Badan Standar Nasional Pendidikan (BSNP) memiliki alokasi waktu 6 jam pelajaran (6 x 40') yang mencakup 5 kingdom klasifikasi makhluk hidup, yaitu kingdom monera, protista, fungi, plantae, dan animalia. Dalam penelitian ini ada tiga pertemuan yaitu pertama membahas materi klasifikasi tumbuhan biji, kedua klasifikasi hewan invertebrata, dan ketiga klasifikasi hewan vertebrata. Waktu yang yang dibutuhkan 8 jam pelajaran, kurang 2 jam untuk materi monera, protista, dan fungi. Kekurangan mengambil dari waktu cadangan yang ada.

1. Pengaruh pembelajaran biologi dengan pendekatan CTL dengan teknik network tree dan spider concept map terhadap hasil belajar peserta didik. Berdasarkan hasil analisis data menggunakan anava tiga jalan diperoleh $p$ value kognitif $0,071>0,05, p$-value afektif $0,000<0,05, p$-value psikomotor $0,027<0,05$. Berdasarkan ketentuan bahwa $p$-value $>0,05$ Ho diterima dan $p$-value $<0,05$ Ho ditolak maka pembelajaran dengan pendekatan CTL dengan teknik network tree dan spider concept map berpengaruh signifikan terhadap hasil belajar afektif dan psikomotor dan tidak berpengaruh signifikan terhadap hasil belajar kognitif.

Pendekatan CTL dengan teknik network tree dan spider concept map memberikan dampak yang relatif sama terhadap hasil belajar kognitif. Peserta didik menerima pembelajaran dengan CTL dengan tujuh komponen yaitu modeling, questioning, inquiry, learning community, contructivism, reflection dan authentic assisment memberikan kontribusi yang baik untuk materi klasifikasi makhluk hidup.
CTL dengan teknik network tree dan spider concept map membuat peserta didik aktif untuk melakukan pengamatan, mengajukan pertanyaan, berkomunikasi kemudian menyimpulkan dengan dituangkan dalam network tree/spider concept map membuat pembelajaran kondusif dengan gerak peserta didik yang aktif (Kang, 2004). Komunikasi dalam pengamatan maupun presentasi membuat peserta didik percaya diri dan merasa dihargai. Selain itu peserta didik juga melakukan pengamatan dengan teliti, tanggung jawab, dan kerja sama yang baik di dalam kelompok maupun dengan kelompok lain juga dengan guru sehingga membentuk sikap yang mandiri dan berkarakter (Miller, 2006).

Pendekatan dan teknik yang tepat dalam pembelajaran mempengaruhi proses pembelajaran (Sari dan Nasikh, 2009). Hal ini relevan dengan teori belajar Bruner bahwa orang yang belajar berinteraksi dengan lingkungan dengan secara aktif perubahan tidak hanya terjadi pada lingkungan tetapi pada diri orang itu sendiri. Interaksi secara langsung antara peserta didik dengan peserta didik maupun peserta didik dengan benda atau lingkungan di sekitarnya dapat mempengaruhi perilaku seseorang (Dahar, 1989).

2. Pengaruh antara kreativitas tinggi dan rendah terhadap hasil belajar peserta didik. Berdasarkan hasil analisis data menggunakan anava tiga jalan diperoleh $p$-value kognitif $0,000<0,05, p$-value afektif $0,005<0,05, p$ value psikomotor $0,629>0,05$. Berdasarkan ketentuan bahwa $p$-value $>0,05$ Ho diterima dan $p$-value $<0,05$ Ho ditolak maka kreativitas tinggi dan rendah berpengaruh signifikan terhadap hasil belajar kognitif dan afektif tetapi tidak berpengaruh signifikan terhadap hasil belajar psikomotor.

Kreativitas tinggi dan rendah memberikan pengaruh yang signifikan terhadap hasil belajar kognitif dan afektif. Kreativitas yang dipunyai oleh peserta didik mempunyai kontribusi terhadap hasil belajar kognitif dan afektif. Hasil belajar peserta didik yang memiliki kreativitas tinggi mempunyai nilai rerata lebih tinggi dari peserta didik yang mempunyai kreativitas rendah (Tabel 2). Munandar (2009) mengatakan bahwa salah satu faktor untuk menentukan keberbakatan seseorang adalah kreativitas untuk berprestasi. 
Kreativitas atau daya cipta memungkinkan penemuan-penemuan baru dalam bidang ilmu dan teknologi serta dalam semua bidang usaha maupun lainnya (Mahardika, 2012).

Dalam proses pembelajaran kreativitas yang dimiliki peserta didik belum sepenuhnya tertuang dalam proses pembelajaran. Peserta didik yang baru kelas tujuh kemungkinan masih ada yang mempunyai rasa malu atau takut untuk melakukan komunikasi, mengajukan pertanyaan baik kepada teman dalam kelompok atau kepada guru. Sedangkan untuk melakukan pengamatan sangat bersemangat. Dengan demikian kreativitas peserta didik kurang memberikan kontribusi terhadap hasil belajar psikomotor.

3. Pengaruh antara gaya berpikir sekuensial dan acak terhadap hasil belajar peserta didik. Berdasarkan hasil analisis data menggunakan anava tiga jalan diperoleh $p$-value kognitif $0,745>0,05, p$-value afektif $0,972>0,05, p$ value psikomotor $0,757>0,05$. Berdasarkan ketentuan bahwa $p$-value $>0,05$ Ho diterima dan $p$-value < 0,05 Ho ditolak maka gaya berpikir tidak memberikan pengaruh signifikan terhadap hasil belajar kognitif, afektif, dan psikomotor.

Dalam penelitian ini gaya berpikir hanya menunjukkan perbedaan perolehan nilai rerata, ditunjukkan bahwa peserta didik yang memiliki gaya berpikir acak memperoleh nilai rerata lebih tinggi dari pada yang mempunyai gaya berpikir sekuensial (Tabel 2). Dalam proses pembelajaran materi klasifikasi makhluk hidup, gaya berpikir tidak memberikan pengaruh yang signifikan terhadap proses pemahaman, kemampuan untuk mengamati, mengajukan pertanyaan, mengkomunikasikan hasil pembelajaran, juga sikap teliti, tanggung jawab dan kerja sama (Rahayu, 2011).

Gaya berpikir adalah suatu bentuk perilaku yang diakibatkan oleh dominansi otak (kiri atau kanan) dalam memproses informasi hingga menciptakan solusi yang lebih seimbang untuk menyelesaikan permasalahan dalam situasi dan kondisi rangsangan yang berbeda-beda seperti pada Gregorc (1982 cit DePorter, 2011). Bahwa otak menyerap dan memproses informasi sesuai dengan gaya berpikir masing-masing tidak memberikan pengaruh yang signifikan. Hal ini kemungkinan karena teknik network tree dan spider consep map haya menyertai pembelajaran yaitu muncul pada akhir pembelajaran pada fase contructivism.

4. Pengaruh interaksi antara pendekatan $C T L$ dengan teknik dengan network tree dan spider concept map dengan kreativitas tinggi dan rendah terhadap prestasi belajar peserta didik. Berdasarkan analisis data menggunakan anava tiga jalan diperoleh $p$-value kognitif $0,581>$ $0,05, p$-value afektif $0,357>0,05$, dan $p$-value psikomotor $0,747>0,05$. Berdasarkan ketentuan bahwa $p$-value $>0,05$ Ho diterima dan $p$-value $<0,05$ Ho ditolak maka interaksi antara pendekatan CTL dengan teknik network tree dan spider concept map dengan kreativitas tidak memberikan pengaruh signifikan terhadap hasil belajar kognitif, afektif, dan psikomotor (Wahyuni, 2012).

Hal ini terjadi kemungkinan karena pendekatan CTL dengan teknik network tree dan spider concept map membuat peserta didik lebih tertarik (Deen, 2006). Akibat ketertarikan tersebut pemahaman, sikap ketelitian, kerja sama, tanggung jawab dan gerak dalam mengamati, mengajukan pertanyaan dan komunikasi dalam penerimaan materi klasifikasi makhluk hidup peserta didik secara umum baik. Begitu juga kreativitas membuat peserta didik tertarik untuk mengikuti pembelajaran.

Menurut teori belajar Ausubel "belajar bermakna (meaningful learning)" yaitu proses belajar dengan menghubungkan informasi baru dengan struktur yang telah dipunyai seseorang yang sedang belajar. Berhubungan dengan kreativitas menurut Munandar (2009) salah satu faktor untuk menentukan keberbakatan seseorang adalah kreativitas untuk berprestasi. Pada pembelajaran materi klasifikasi makhluk hidup teknik nekwork tree dan spider concept map dan kreativitas yang dimiliki peserta didik memberikan kontribusi yang sama terhadap hasil belajar, sehingga tidak ada pengaruh interaksi yang signifikan.

5. Pengaruh interaksi antara pendekatan $C T L$ dengan teknik network tree dan spider concept map dengan gaya berpikir sekuensial dan acak terhadap prestasi belajar. Berdasarkan hasil analisis data menggunakan anava tiga jalan diperoleh $p$-value kognitif $0,337>0,05, \quad p$ value afektif $0,948>0,05$, dan $p$-value 
psikomotor $0,006<0,05$. Berdasarkan ketentuan bahwa $p$-value $>0,05$ Ho diterima dan $p$-value $<0,05$ Ho ditolak maka interaksi antara network tree dan spider concept map dengan gaya berpikir memberikan pengaruh signifikan terhadap hasil belajar psikomotor dan tidak memberikan pengaruh signifikan terhadap hasil belajar kognitif dan afektif.

Hal ini terjadi kemungkinan karena interaksi antara pendekatan CTL dengan teknik network tree dan spider concept map dengan gaya berpikir mempunyai kontribusi yang sama terhadap hasil belajar kognitif dan afektif. Sehingga network tree dan spider concept map sebagai teknik membantu peserta didik menghubungkan konsep satu dengan yang lain dalam materi klasifikasi makhluk hidup dengan gaya berpikir dominansi otak kiri dan kanan dalam memproses informasi tidak memberikan pengaruh yang signifikan terhadap pemahaman materi, sikap teliti, tanggung jawab, dan kerja sama dalam proses pembelajaran.

Hasil uji lanjut anava interaksi yang mempunyai pengaruh lebih besar adalah pendekatan CTL dengan teknik network tree dan spider concept map dengan gaya berpikir sekuensial dengan signifikasi 0,002 (Tabel 4). Pembelajaran sains khususnya biologi tidak hanya berupa transfer pengetahuan saja tetapi juga bagaimana cara memperoleh penegetahuan tersebut. Menurut Gagne (1984 dalam Dahar, 1989) yang yaitu "belajar adalah suatu proses dimana suatu organisma berubah perilakunya sebagai akibat pengalaman". Oleh karena itu dalam proses belajar mengajar biologi yang terpenting adalah pengalaman yang dapat membuat perubahan tingkah laku yang dapat diamati dan dapat diukur. Tingkah laku dalam penelitian ini adalah mengamati, mengajukan pertanyaan, dan berkomunikasi.

6. Pengaruh interaksi antara pengaruh interaksi antara kreativitas tinggi dan rendah dengan gaya berpikir sekuensial dan acak terhadap hasil belajar. Berdasarkan analisis data menggunakan anava tiga jalan diperoleh $p$ value kognitif $0,017<0,05$, p-value afektif $0,348>0,05$ dan $p$-value psikomotor $0,273>$ 0,05 . Berdasarkan ketentuan bahwa $p$-value $>$ 0,05 Ho diterima dan $p$-value $<0,05$ Ho ditolak maka interaksi antara kreativitas tinggi dan rendah dengan gaya berpikir sekuensial dan acak memberikan pengaruh signifikan terhadap hasil belajar kognitif dan tidak memberikan pengaruh signifikan terhadap hasil belajar afektif dan psikomotor.

Interaksi antara kreativitas dan gaya berpikir dalam materi klasifikasi makhluk hidup memberikan pengaruh yang signifikan terhadap pemahaman konsep materi klasifikasi makhluk hidup, karena peserta didik yang mempunyai kreativitas tinggi cenderung mempunyai kemampuan memahami materi lebih baik dari pada yang mempunyai kreativitas rendah. Peserta didik yang mempunyai gaya berpikir acak cenderung mempunyai keinginan melakukan coba-salah (trial and error) sehingga sering terjadi lompatan intuitif. Sebaliknya peserta didik yang berpikir sekuensial cenderung untuk berpikir sistematis dan teratur. Hasil uji lanjut anava menunjukkan interaksi antara kreativitas rendah dan tinggi dengan gaya berpikir acak memberikan pengaruh yang signifikan terhadap hasil belajar kognitif peserta didik dengan signifikasi 0,001 (Tabel 5).

Peserta didik yang memiliki ciri-ciri kreativitas menurut Munandar (2009) diantaranya adalah rasa ingin tahu yang luas dan mendalam, sering mengajukan pertanyaan yang baik, memberikan banyak gagasan dan mempunyai daya imajinasi. Dalam pembelajaran klasifikasi makhluk hidup peserta didik yang memiliki kreativitas tinggi akan cenderung mengembangkan ide-idenya didukung dengan gaya berpikir yang dimiliki. Hal ini sesuai dengan ciri gaya berpikir acak, bahwa peserta didik mampu menyelesaikan tugasnya sendiri dengan cara mereka sendiri walaupun sering terjadi kesalahan-kesalahan, namun tidak membuat putus asa untuk terus mencoba, sehingga sering terjadi lompatan intuitif ketika menyelesaikan tugasnya (DePorter, 2011).

7. Pengaruh interaksi antara pendekatan CTL dengan teknik network tree dan spider concept map, kreativitas tinggi dan rendah dengan gaya berpikir sekuensial dan acak terhadap hasil belajar. Berdasarkan analisis data menggunakan anava tiga jalan diperoleh $p$-value kognitif $p$ value $0,989>0,05, p$-value afektif $0,366>0,05$ dan $p$-value psikomotor $0,542>0,05$. Berdasarkan ketentuan bahwa $p$-value $>0,05$ Ho diterima dan $p$-value $<0,05$ Ho ditolak maka interaksi antara pendekatan CTL dengan 
teknik network tree dan spider concept map, kreativitas tinggi dan rendah dengan gaya berpikir sekuensial dan acak tidak memberikan pengaruh signifikan terhadap hasil belajar kognitif, afektif, dan psikomotor.

Interaksi antara pembelajaran biologi dengan pendekatan CTL dengan teknik network tree dan spider concept map, kreativitas tinggi dan rendah dengan gaya berpikir sekuensial dan acak tidak memberikan pengaruh yang signifikan terhadap hasil belajar kognitif, afektif, dan psikomotor. Menurut Ausubel (1960 dalam Dahar, 1989) belajar dapat diklasifikasikan ke dalam dua dimensi. Dimensi pertama berhubungan dengan cara informasi atau materi pelajaran disajikan pada siswa melalui penerimaan atau penemuan. Dimensi kedua menyangkut cara bagaimana siswa dapat mengaitkan informasi itu pada struktur kognitif yang telah ada. Menurut Piaget perkembangan kognitif dipengaruhi oleh tiga proses dasar, yaitu asimilasi, akomodasi, dan ekuilibrasi. Pemaduan materi klasifikasi makhluk hidup yang telah ada disesuaikan dengan materi yang diterima kemudian disusun menjadi konsep klasifikasi yang sempurna.

Dari hasil analisis di atas dapat dijelaskan bahwa teknik nertwork tree dan spider concept map yang diinteraksikan dengan kreativitas dan gaya berpikir menjadikan hasil belajar yang diperoleh dari kedua kelompok penelitian tidak berbeda. Dengan tidak adanya perbedaan yang signifikan menunjukkan bahwa ketiga variabel yang diinteraksikan saling independen.

Tabel 6. Rangkuman Hasil Pengujuan Hipotesis

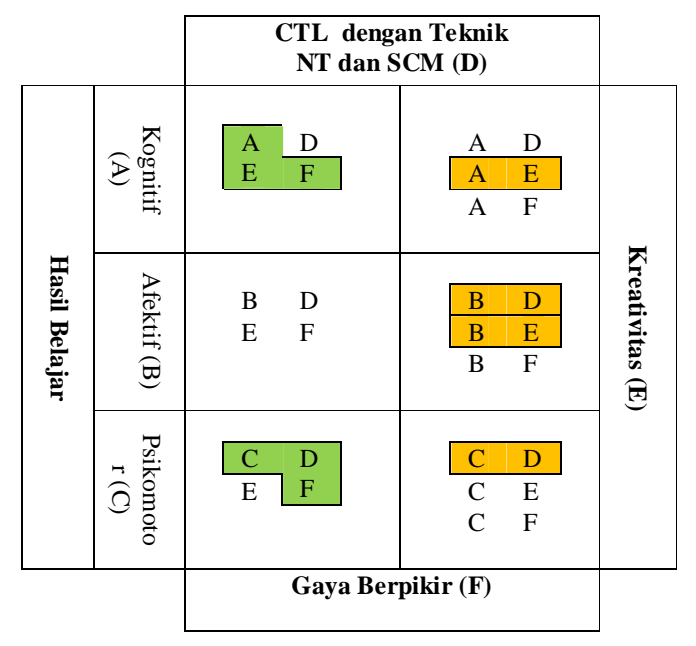

Ket: $₫$ ada pengaruh ada interaksi
1. Pendekatan CTL dengan network tree dan spider concept map bagi peserta didik yang mempunyai kreativitas tinggi akan berpengaruh terhadap hasil belajar kognitif dan afektif tetapi tidak berpengaruh terhadap hasil belajar psikomotor.

2. Jika ada pengaruh antara hasil belajar kognitif maupun psikomotor dengan variabel lain, dapat menyebabkan terjadinya interaksi dengan variabel yang lain pula.

3. Jika ada pengaruh antara hasil belajar afektif dengan salah satu atau lebih variabel yang lain tidak menyebabkan terjadinya interaksi seluruh variabel.

4. Hasil belajar kognitif dan psikomotor memiliki pengaruh untuk terjadinya interaksi antar variabel.

\section{Kesimpulan dan Rekomendasi}

Berdasarkan hasil penelitian pada materi klasifikasi makhluk hidup kelas VII SMPN 1 Sukosewu Bojonegoro Tahun Pelajaran 2012/2013 dan pembahasan di atas maka dapat disimpulkan bahwa: 1. ada pengaruh penggunaan pendekatan CTL dengan teknik network tree dan spider concept map terhadap hasil belajar afektif dan psikomotor peserta didik, sedangkan kognitif tidak ada pengaruh; 2. ada pengaruh kreativitas tinggi dan rendah terhadap hasil belajar kognitif dan afektif peserta didik, sedangkan psikomotor tidak ada pengaruh; 3. tidak ada pengaruh gaya berpikir sekuensial dan acak terhadap hasil belajar kognitif, afektif, dan psikomotor peserta didik; 4. tidak ada interaksi antara pendekatan CTL dengan teknik network tree dan spider concept map dengan kreativitas terhadap hasil belajar kognitif, afektif, dan psikomotor peserta didik; 5. ada interaksi antara pendekatan CTL dengan teknik network tree dan spider concept map dengan gaya berpikir terhadap hasil belajar psikomotor peserta didik, sedangkan kognitif dan afektif tidak ada interaksi; 6. ada interaksi antara kreativitas dan gaya berpikir terhadap hasil belajar kognitif peserta didik, sedangkan afektif dan psikomotor tidak ada interaksi; 7 . tidak ada interaksi antara pendekatan CTL dengan teknik network tree dan spider concept map, kreativitas dan gaya berpikir terhadap hasil belajar kognitif, afektif, dan psikomotor peserta didik.

Berdasarkan hasil penelitian ini, bagi pendidik dapat menggunakan pendekatan CTL 
dengan teknik network tree dan spider concept map dengan memperhatikan kemampuan kreativitas dan gaya berpikir. Bagi peneliti lain perlu penelitian lebih lanjut dengan meningkatkan dan mengembangkan kualitas proses pendekatan CTL dengan teknik network tree dan spider concept map dengan variabel moderator yang berbeda seperti motivasi belajar, gaya belajar, sikap ilmiah, dan kemampuan berpikir abstrak. Validasi instrumen yang lebih cermat dan teliti. Pengukuran kreativitas peserta didik perlu ditingkatkan menjadi kategori tinggi, sedang dan rendah untuk memperjelas batas-batas kemampuan kreativitas. Dalam pengambilan data nilai kognitif selain menggunakan tes prestasi perlu dilakukan juga terhadap penilaian lembar kerja peserta didik (LKPD).

\section{Daftar Pustaka}

Berns, RG. and Erickson, PM. (2001). Contextual Teachig and Learning: Preparing Students for the New Economy. J. Center Tecnocal Education. No.5: 1-8.

BSNP. (2006). Panduan Penyusunan Kurikulum Tingkat Satuan Pendidikan. Jenjang Pendidikan Dasar dan Menengah. Jakarta: Badan Standar Nasional Pendidikan.

Dahar. (1989). Teori-Teori Belajar. Jakarta: Erlangga.

Deen, IS. (2006). Contextual Teaching and Learning Practices In The Family And Consumer Sciences Curriculum. J. of Family and Consumer Sciences Education, 24(1): 14-27.

Depdiknas. (2005). Peraturan Pemerintah Nomor 19 Tahun 2005 tentang Standart Nasional Pendidikan. Jakarta: Biro Hukum dan organisasi.

DePorter, B. \& Hernacki, M. (2011). Quantum Learning. (Terjemahan). Bandung: Kaifa.

Fuata'i, KA. (2004). Concept Maps and Vee Diagram as Tools For Learning New Mathematics Topics pp 1-8 dalam Canas, A.J. Novak, J.D. Gonzales, F.M. (Eds). 2004. Proc. Of the First Int. Confereence. University of New England.

Hay, DB. Kehoe, C. and Miquei, EM. (2008). Measuring the Quality of E-Learning. J. of Educatian Technology, 39(6): 1037-1056.

Johnson, EB. (2011). CTL Contectual Teaching \& Learning Menjadikan Kegiatan Belajar Mengajar Mengasyikkan dan Bermakna. Penerjemah: Ibnu Setiawan. Bandung: Kaifa.
Kang, S. (2004). Using Visual Organizing to Enhance EFL Instruction. J. ELT, 58(1): 5867.

Mahardika, A. (2012). Pembelajaran Fisika dengan Konstektual Menggunakan Metode Eksperimen dan Demonstrasi Ditinjau dari Kreativitas dan Motivasi Berprestasi Siswa. Tesis FPS UNS. Surakarta. (Unpublished).

Miller, PM. (2006). Contectual Learning May be a Better Teaching Model: Acare For Higher Order Learning and Transfer. Proceedings of the Academy of Educational Leadership. 11(2): 19-23.

Mukayatun. (2011). Dokumen Kumpulan Nilai Ulangan Harian Semester Gasal 2011/2012. Bojonegoro. (Unpublished).

Munandar. (2009). Keativitas Anak Berbakat. Jakarta: Rineka Cipta.

Nurdin. (2009). Implementasi Pendekatan CTL (Contextual Teaching and Learning) dalam Meningkatkan Hasil Belajar. Jurnal Adminstrasi Pendidikan IX (1): 109-123.

Polancos, DT. (2011). Effects of Vee Diagram and Concept Mapping on the Achievement of Students in Chemistry. Abstr. 7(1): 1.

Rahayu, P. (2011). Pembelajaran Fisika dengan TGT Menggunakan Permainan Wordsquare dan Crossword Ditinjau dari Keingintahuan. Tesis FPSUNS. Surakarta. (Unpublished).

Ristasa, R. (2012). Model Tutorial Berbasis Ketrampilan Proses Sains dengan Menggunakan Lingkungan Riil dan Lingkungan Virtuil Ditinjau dari Gaya Belajar dan Gaya Berpikir. Tesis FPS UNS. Surakarta. (Unpublished).

Rustaman, N. (2005). Strategi Belajar Mengajar Biologi. Malang: UM Press.

Sari, NF. dan Nasikh. (2009). Efektivitas Penerapan Pembelajaran Bebasis masalah dan Teknik Peta Konsep dalam meningkatkan Proses dan Hasil Belajar Mata Pelajaran Ekonomi Siswa Kelas X6 SMAN 2 Malang Semester Genap Tahun Ajaran 2006/2007. JPE 2(1): 53-73.

Slameto, (2010). Belajar dan faktor-Faktor yang Mempengaruhinya. Jakarta: Rineka Cipta.

Suparno, P. (2005). Teori Perkembangan Kognitif Jean Piaget. Yogyakarta: Kanisius.

--------------, (2012). Filsafat Konstruktivisme dalam Pendidikan. Yogyakarta: Kanisius.

Trianto. (2008). Mendesain Pembelajaran Kontekstual (Contextual Teaching and Learning) di kelas. Jakarta: Cerdas Pustaka Publisher.

--------, (2011), Mendesain Model Pembelajaran Inovatif-Progresif, Jakarta: Kencana.

Wahyuni, S. (2012). Pendekatan Pembelajaran CTL (Contextual Teaching and Learnin) dengan Metode Problem Solving dan Problem Posing Ditinjau dari Kemampuan Berpikir Kritis dan 
JURNAL INKUIRI

ISSN: 2252-7893, Vol 2, No 12013 (hal 14-24)

http://jurnal.fkip.uns.ac.id/index.php/sains

Kemampuan Berkomunikasi Verbal. Tesis FPSUNS. Surakarta. (Unpublished).

Wasis, (2006). Contextual Teaching and Learning (CTL) dalam Pembelajaran Sains Fisika SMP, Cakrawala Pendidikan, XXV(1): 116. 